\title{
Prevalence and determinants of TB infection in a rural population in northeastern Myanmar
}

Theint Theint Lwin' ${ }^{1}$, Tawatchai Apidechkul ${ }^{1,2^{*}}$, Jongkon Saising ${ }^{1}$, Panupong Upala², Ratipark Tamornpark², Chalitar Chomchoei ${ }^{2}$, Fartima Yeemard ${ }^{2}$, Wipob Suttana ${ }^{1}$ and Rachanee Sunsern ${ }^{1}$

\begin{abstract}
Background: Tuberculosis (TB) is a major human threat, as evidenced by the large numbers of cases and deaths, particularly in developing countries with poor economic and educational statuses. Myanmar has one of the highest TB burdens in the world, but no TB information is available for people living in the rural northeastern regions of Myanmar. The present study estimated the prevalence of TB and identified factors associated with TB infection in people living in rural communities in Shan State.

Methods: A cross-sectional study was performed to gather information from participants. People aged 18-59years who lived in the three areas with the highest numbers of TB cases in Shan State in northeastern Myanmar were included in the study population. A simple random method was used to select the sample from the villages. A validated questionnaire was used for data collection in face-to-face interviews after obtaining signed informed consent from the selected participants. The Mantoux tuberculin skin test (TST) was administered to detect TB infection, and a result that was $10 \mathrm{~mm}$ or greater after $48 \mathrm{~h}$ was considered positive. Chi-squared tests and logistic regression were used to identify the associations between the variables at a significance level of $a=0.05$.

Results: A total of 303 participants were recruited for the study; $64.7 \%$ were females, and the mean age was 37 years $(S D=12.5)$. Most participants were Burmese $(25.4 \%)$, and $14.95 \%$ were Shan. Sixty-three participants (20.8\%) had a positive TST. Four variables were associated with TB infection in the multivariate model. Males had a greater chance of TB infection than females ( $A O R=2.51 ; 95 \% \mathrm{Cl}=1.32-4.76)$. Participants who were ever married had a greater chance of TB infection than participants who were single (AOR $=3.93 ; 95 \% \mathrm{Cl}=1.18-13.00)$. Participants who used wood and charcoal as their main sources of energy for cooking had a greater chance of TB infection than participants who used electricity ( $A O R=4.23 ; 95 \% \mathrm{Cl}=1.25-9.64)$. Participants who had a low level of TB prevention and care knowledge had a greater chance of TB infection than participants with a high level of TB prevention and care knowledge $(\mathrm{AOR}=4.49 ; 95 \% \mathrm{Cl}=1.88-10.72)$.

(Continued on next page)
\end{abstract}

\footnotetext{
* Correspondence: Tawatchai.api@mfu.ac.th

${ }^{1}$ School of Health Science, Mae Fah Lunag University, Chiang Rai 57100,

Thailand

${ }^{2}$ Center of Excellence for Hill Tribe Health Research, Mae Fah Luang

University, Chiang Rai, Thailand
}

(c) The Author(s). 2020 Open Access This article is licensed under a Creative Commons Attribution 4.0 International License, which permits use, sharing, adaptation, distribution and reproduction in any medium or format, as long as you give appropriate credit to the original author(s) and the source, provide a link to the Creative Commons licence, and indicate if changes were made. The images or other third party material in this article are included in the article's Creative Commons licence, unless indicated otherwise in a credit line to the material. If material is not included in the article's Creative Commons licence and your intended use is not permitted by statutory regulation or exceeds the permitted use, you will need to obtain permission directly from the copyright holder. To view a copy of this licence, visit http://creativecommons.org/licenses/by/4.0/. The Creative Commons Public Domain Dedication waiver (http://creativecommons.org/publicdomain/zero/1.0/) applies to the data made available in this article, unless otherwise stated in a credit line to the data. 
(Continued from previous page)

Conclusions: Public health programs that focus on improving knowledge of TB prevention and care and avoiding the use of wood and charcoal as the primary sources of energy for cooking, particularly in males and ever-married individuals, are urgently needed.

Keywords: Tuberculosis, Tuberculin skin test, Associated factors, Myanmar, Rural population

\section{Background}

Tuberculosis (TB) is a major public health burden $[1,2]$, particularly in developing countries [3], and it is one of the top 10 most lethal diseases worldwide. The World Health Organization (WHO) [1] estimated that 10 million (9.0-11.1 million) people suffered from TB infection in 2018, and it forecasted that more than 40 million cases will be reported globally between 2018 and 2022 [2]. Generally, TB infection occurs in major vulnerable populations, such as children with poor nutritional status [4] and people with poor immune systems, particularly people who are infected with human immunodeficiency virus (HIV) $[5,6]$. The development of TB is related to other specific population characteristics, such as poverty [7], poor education [8], poor access to health care [9] and residence in cities or countries undergoing civil conflict [10]. Therefore, TB is a human health problem that also reflects inequity in human society, particularly access to public services and quality of life in different populations.

Myanmar is ranked 139th in the world economic rankings, and it is classified as a poor country (lower-middle income economy), with a gross domestic product (GDP) per capita of $\$ 6509$ in 2018 [11]. There were approximately 52.6 million people from more than 135 ethnic groups living in Myanmar in 2019 [12]. Shan is a Myanmar state with a relatively large population of minority groups, who account for $10.0 \%$ of the Myanmar population and live in the northern region, especially along the border of northern Thailand [13]. These groups live in poor economic and educational conditions, and there is civil conflict between the central Myanmar government and the minority populations in the northern region of Myanmar. The WHO reported that there were 137,972 new and relapsed TB cases in 2018 in Myanmar [14]. Myanmar was ranked as one of the 20 countries with the highest TB burdens in the world with a total TB incidence of 181,000 (119,000-256, 000) cases $(338 / 100,000$ population) [14], which indicates that these groups of people are obviously vulnerable to TB infection.

However, there is no public health information on TB in particular minority groups in northeastern Myanmar. Based on medical information from Thai hospitals located along the border of Thailand and Myanmar, which people in Shan State generally use when they have a medical problem, more than 150 new TB cases are diagnosed and treated annually [15]. Greater than $80.0 \%$ of TB cases are reported in people ranging from 18 to 59 years [15]. However, several aspects of the treatment process, including case management, require at least 6 months for a complete treatment cycle, and patients often must be admitted to a hospital, particularly in the early period [16]. Thailand has an excellent health care system and health insurance. However, the universal coverage scheme only covers people who are Thai citizens, and it does not cover charges for any medical treatment or care in a public hospital accessed by nonThai citizens [17]. Therefore, all TB patients from outside of Thailand are asked to pay for medical treatment and care [18], and treatment is not affordable for patients from Myanmar. The magnitude of the TB problem and its determinants in these populations must be assessed before proper public health interventions may be implemented in these populations. The ultimate global goal of the United Nations (UN) mission is to eradicate TB by 2030 [19].

Therefore, the current study estimated the prevalence of TB infection in a community in the rural northeastern area of Myanmar and determined the factors associated with TB infection.

\section{Methods}

Study design

A cross-sectional design was used to collect data from the participants.

\section{Study setting}

The study was performed in the three villages with the highest TB incidence rates in Myanmar, according to a published report [20]. These villages were in the Ta Chi Leik District, Shan State, Myanmar.

\section{Study population}

People aged 18-59 years, which was the age group with the highest reported TB incidence rate, who lived in the study area constituted the study population [20].

\section{Eligible population}

People aged 18-59 years who had lived in the study area for at least 3 years were eligible for the study. People who could not provide essential information on the 
questionnaire or who refused to undergo TB detection using a tuberculin skin test (TST) were excluded from the study.

\section{Sample size}

The sample size was calculated using the standard formula for a cross-sectional design [21]:

$$
\mathrm{n}=\left[\mathrm{Z}^{2}{ }_{\alpha / 2} \mathrm{PQ}\right] / \mathrm{e}^{2} .
$$

The value of $p=24.3 \%$ was taken from a study on the prevalence of latent tuberculosis infection and associated risk factors in China [22], and other values were $\mathrm{q}=$ $7.57 \%, \mathrm{e}=5.0 \%$, and $\mathrm{Z}=1.96$. After adding a $10.0 \%$ error for the study, a total of 303 individuals were needed for the analysis.

\section{Research instruments}

A questionnaire that was validated using the itemobjective congruence (IOC) method and piloted was used for data collection. It was divided into 6 parts. First, 10 questions were used to collect general information from the participants, such as age, sex, marital status, and education. Second, 13 questions were used to collect health information and factors related to $\mathrm{TB}$, such as a history of Bacillus Calmette-Guérin (BCG) vaccination, a history of TB diagnosis and treatment, and medical expenses related to treatment. Third, 16 questions were used to collect data on personal risk behaviors and living environment, such as "Do you smoke?", "Do you drink alcohol?", and "What kind of fuel do you use for daily cooking?" Fourth, 20 questions were used to detect knowledge and attitudes of TB prevention and care. Ten questions were asked on knowledge related to TB prevention and care. Each question in this section was scored as 0 for an incorrect answer and 1 for a correct answer. Participants who received scores of $0-5$ were classified as having "poor" knowledge, participants with scores of 6-8 were classified as having "moderate" knowledge, and participants with scores of 9-10 were classified as having "good" knowledge. Another 10 questions were asked on attitudes related to TB prevention and care. Each question was rated on a five-point scale ranging from totally agree to totally disagree. Positiveattitude questions were scored as 5 (i.e., for responses of totally agree), and these scores decreased based on the increasing negativity of the attitude, with a score of 0 given for answers conveying disagreement. Negativeattitude questions were scored as 0 for responses of totally agree, with scores increasing to 5 for a response of totally disagree. There were 5 negative-attitude questions and 5 positive-attitude questions. People who scored fewer than 26 points were classified as having a poor attitude, participants who scored $26-40$ were classified as having a moderate attitude, and participants who scored 41 and over were classified as having a good attitude towards TB treatment and care. Fifth, 8 questions were used for the clinical assessment and PPD tests, such as "Have you had a cough for more than two weeks in the past six months?", "Have you experienced weight loss during the past six months?", and "Do you have a lowgrade fever in the evening?". The last part included 3 items about the TST test and was completed by a medical doctor from one of the research teams.

The questionnaire was further developed to improve its validity and reliability before use in the field. The IOC method was used to detect its validity by three external experts in the fields of infectious disease, medical immunology, and public health. Questions with scores less than 0.50 were deleted, those with scores of 0.510.70 were revised, and those with scores greater than 0.70 were included in the questionnaire. A pilot was performed with 15 selected individuals who had similar characteristics to the villagers in Ta Chi Leik District, Shan State, Myanmar. The purposes the pilot study were to detect the feasibility and order of the questions in the questionnaire and the reliability of the questions on knowledge and attitude. Finally, Cronbach's alpha of the knowledge and attitude questions was 0.77 .

The Mantoux TST was used to identify TB infections in the selected participants. Tuberculin-purified protein derivative (PDD), which was produced by the Thai Red Cross (Thai Red Cross Tuberculin PPD ${ }^{\circ}$ ), was used for the TST [23], with $94.0 \%$ sensitivity and $88.0 \%$ specificity.

All selected participants were injected with $0.1 \mathrm{~mL}$ of tuberculin PDD in the inner surface of the forearm. The induration was measured in millimeters $48 \mathrm{~h}$ after the injection. An induration of 10 or more millimeters was considered positive for $\mathrm{TB}$ infection, according to the recommendation of the Centers for Disease Control and Prevention (CDC) in the United States [24].

\section{Data collection procedures}

The head of the Department of National TB Control of Myanmar was contacted to obtain approval for conducting research in Myanmar. Afterward, Ta Chi Leik District health officers were contacted regarding the study and were asked to communicate with 3 village headmen. The list of people who met the criteria was obtained from the village headmen: 201 people from village No. 1; 335 people from village No. 2; and 139 people from village No. 3. A random method was used to select the 303 required participants from the lists of villagers. All selected participants were provided with all essential information and were invited to participate in the study in Burmese. The questionnaire took 20 min to complete. 


\section{Statistical analysis}

Information from the questionnaires was converted into code and double entered into an Excel sheet. Analyses were performed using SPSS version 24, 2016 (SPSS, Chicago, IL). Descriptive statistics were used to describe the participants' characteristics. Logistic regression was used to determine associations between the variables in univariate and multivariate models at the level of alpha = 0.05. The "ENTER" method was used in univariate and multivariate analyses. All independent variables in the univariate model were associated with $\mathrm{TB}$ infection in an independent process at the significance level of 0.05 , and crude odds ratios (COR) were generated. All independent variables were included in the multivariate model simultaneously, and variables that were not significant were deleted individually, starting with the variable with the largest $p$-value (over 0.05 ), until only the significant variables ( $\mathrm{p}$-value less than 0.05 ) remained in the model. The model was preliminarily interpreted. Age, religion, education and ethnicity were controlled as confounding factors in the model. The final interpretations of the adjusted odds ratios (AORs) were made. During the analysis, some variables, such as attitude related to TB prevention and care and knowledge related to $\mathrm{TB}$ prevention and care, were grouped into smaller categories because a few samples were counted into that cell. The reason was to improve the power of the test and meet the criteria of the statistics used.

\section{Results}

A total of 303 participants participated from three different villages: 97 participants were from village No. 1; 140 participants were from village No. 2; and 66 participants were from village No. 3. More than half of the participants were females (64.7\%), married (65.7\%) and Christian (56.1\%). The mean age was 37.0 years, and $40.3 \%$ of the participants were Shan and Burmese. Most participants had a low education level $(41.6 \%$ were not educated) and poor economic status (41.9\%), with incomes equal to or less than 100,000 kyat per month (\$65) (Table 1).

Fifty-one (16.8\%) participants were defined as underweight. Only $56.1 \%$ had a history of receiving the BCG vaccination, $38.3 \%$ had at least one family member who had been infected with TB in the past, and most had received treatment and care at a government hospital. A few people had been screened for TB (2.0\%), and onefourth had been tested for HIV/AIDS. Most of the participants lived less than $5 \mathrm{~km}$ from a health care center (97.0\%) but needed transportation to a health care center that cost less than 5000 kyat (\$3.39) per visit. Half of the participants (48.2\%) had no right to access free-ofcharge medical services, and a large proportion (75.2\%) experienced language barriers while attending a clinic.
More than half (58.1\%) of the participants had a low level of knowledge and a negative attitude (63.4\%) toward TB prevention and care.

The overall prevalence of TB infection was 20.8\%: $20.6 \%$ in village No. $1,20.7 \%$ in village No. 2 , and $21.2 \%$ in village No. 3 (Table 2).

The health behaviors of the participants revealed that $22.4 \%$ smoked, $13.9 \%$ consumed alcohol, 3.3\% used heroin, and 5.9\% used amphetamines (Table 3).

More than half of the participants (59.4\%) lived in brick houses. A total of $77.6 \%$ cooked indoors, and $73.6 \%$ used wood and charcoal as their main sources of fuel for indoor cooking (Table 4).

The univariate model found that 12 variables were associated with TB infection: sex, marital status, education, having family member(s) with a history of TB disease, smoking, number of cigarettes smoked per day, heroin use, amphetamine use, main source of energy for cooking, distance to health center, experiencing language barriers when accessing health care, and knowledge of TB prevention and care (Table 5).

However, only 4 variables remained associated with TB infection in the multivariate model after controlling for age, religion, education and ethnicity: sex, marital status, main source of energy for cooking, and knowledge of TB prevention and care. Males had a greater chance of TB infection than females $(\mathrm{AOR}=2.51 ; 95 \%$ $\mathrm{CI}=1.32-4.76)$. Participants who were ever married had a greater chance of $\mathrm{TB}$ infection than participants who were single $(\mathrm{AOR}=3.93 ; 95 \% \mathrm{CI}=1.18-13.00)$. Participants who used wood and charcoal as their main sources of energy for cooking had a greater chance of TB infection than participants who used electricity $(\mathrm{AOR}=4.23$; 95\% CI $=1.25-9.64)$. Participants who had a low level of knowledge of TB prevention and care had a greater chance of TB infection than participants who had a high level of knowledge of TB prevention and care (AOR = 4.49; 95\% CI = 1.88-10.72) (Table 5).

\section{Discussion}

People in rural areas in Myanmar, particularly people aged 18-59 years, were living with a high prevalence of TB infection (28.0\%). This population generally had a poor economic status and low education level. A large proportion of the people had low knowledge of and negative attitudes towards TB prevention and care. The coverage of BCG vaccination and TB screening was also low. Male sex, ever-married status, use of wood and charcoal as the main sources of energy for cooking, and poor knowledge of TB prevention and care were strongly associated with TB infection.

The prevalence of TB in the present study was higher than the overall TB case prevalence in Myanmar, which is $0.3 \%$, as reported in the $2018 \mathrm{~TB}$ country profile from 
Table 1 General characteristics of the participants

\begin{tabular}{lll}
\hline Characteristics & $\mathbf{n}$ & $\mathbf{\%}$ \\
\hline Total & $\mathbf{3 0 3}$ & $\mathbf{1 0 0 . 0}$ \\
Sex & & \\
$\quad$ Male & 107 & 35.3 \\
$\quad$ Female & 196 & 64.7 \\
Age (years) & & \\
$\quad$ 18-24 & 61 & 20.1 \\
$24-34$ & 82 & 27.1 \\
$35-44$ & 61 & 20.1 \\
$45-54$ & 66 & 21.8 \\
$\quad \geq 55$ & 33 & 10.9 \\
Mean $=37.0$, SD $=12.5$ & &
\end{tabular}

\section{Religion}

Buddhist

Christian

Other

Ethnicity

Burmese
Shan
Ahka
Lahu

Other

\section{Marital status}

Single

Married

Ever married

\section{Education}

Illiterate
Primary school
Secondary school
High school
University

Occupation

Unemployed
Unskilled labor
Private employer
Government staff
Own business
Family income (kyat)
$\leq 100,000$
100,001-200,000
200,001-400,000
$>400,000$

No. of family members (persons)
Table 1 General characteristics of the participants (Continued)

\begin{tabular}{ccl}
\hline Characteristics & $\mathbf{n}$ & $\%$ \\
\hline $6-10$ & 92 & 30.4 \\
$>10$ & 8 & 2.6 \\
Length of residence in this village (years) & \\
$\leq 10$ & 136 & 44.9 \\
$11-20$ & 59 & 19.5 \\
$>20$ & 108 & 35.6 \\
\hline
\end{tabular}

the WHO [25]. However, this result may not be completely comparable because there were different sources of data, different target populations, and different definitions. Our study estimated the prevalence of TB infection, and the $\mathrm{WHO}$ reported the prevalence of TB cases. The WHO reported the prevalence rates for the overall country and all age categories, and we selected villages with the highest caseloads based on data from local hospitals and focused only on people aged $18-59$ years. The villages were specifically chosen because they were in the areas with the highest numbers of TB cases. The report from the WHO was based on walk-in cases in all health care centers, and the current study investigated communities based on nonclinical signs and presenting symptoms of TB infection. However, both sources of information are crucial for policy makers in Myanmar. The WHO data represent the situation nationwide, particularly the burden on health care services, and the community-based data in the present study reflected the magnitude of undetected TB cases and clearly presented the determinants of TB infection in rural Myanmar, especially ethnic minority populations. A mass screening program to identify latent $\mathrm{TB}$ cases in communities and providing proper treatment are recommended. Health policy makers should be concerned with strengthening health care systems, particularly improvements in infrastructure and health professional skills in TB treatment and care. Health education on TB prevention and control should be implemented for people living in remote areas.

Our study identified the factors associated with TB infection in people living in rural Myanmar. Males had a greater chance of TB infection than females. This result is supported by a 2018 systematic review on TB burden in several low- and middle-income countries, which showed that males had a greater chance of TB infection than females [26]. A study in Brazil also reported that males had a higher rate of TB infection than females in people who had a history of close contact with TB patients [27]. A prospective cohort study in Taiwan clearly showed that males had a greater chance of TB infection than females [28]. Most males had more harsh working conditions than females, and males were more likely to 
Table 2 Medical-related information of the participants

\begin{tabular}{lcc}
\hline Medical information & $\mathbf{n}$ & $\%$ \\
\hline BMI $\left(\mathrm{kg} / \mathrm{m}^{2}\right)$ & & 16.8 \\
Underweight $(<18.5)$ & 51 & 57.1 \\
Normal (18.5-24.9) & 173 & 21.1 \\
Overweight (25-29.9) & 64 & 5.0 \\
Obese ( $\geq 30.0)$ & 15 & \\
History of having BCG vaccine & & 43.9 \\
No & 133 & 56.1 \\
Yes & 170 & \\
Family member(s) with history regarding TB disease & \\
Yes & 116 & 38.3 \\
No & 187 & 61.7
\end{tabular}

Place of TB diagnosis for those who had a history of TB disease

$\begin{array}{lll}\text { Government hospital } & 112 & 96.6 \\ \text { Private hospital } & 2 & 1.7 \\ \text { Others } & 2 & 1.7\end{array}$

History of receiving TB treatment

$\begin{array}{lll}\text { Yes } & 113 & 97.4\end{array}$

No

Completed treatment

$\begin{array}{lll}\text { Yes } & 111 & 98.2\end{array}$

No 2

Length of completed TB treatment (months)

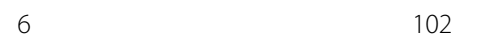

91.9

8

9

Contact with someone with prolong coughing

$\begin{array}{lll}\text { Yes } & 140 & 46.2 \\ \text { No } & 163 & 53.8\end{array}$

Place of contact history

$\begin{array}{lll}\text { Work-place } & 17 & 12.2 \\ \text { Camp } & 44 & 31.4 \\ \text { Household } & 79 & 56.4\end{array}$

History of TST test

Yes

No

Do not know

10

HIV/AIDS test

Yes

No

Diabetes mellitus

Yes

No

Distance to the health center (miles)

$$
\begin{array}{ll}
\leq 5 & 294 \\
>5 & 9
\end{array}
$$

Table 2 Medical-related information of the participants (Continued)

\begin{tabular}{lcl}
\hline Medical information & $\mathbf{n}$ & $\%$ \\
\hline Transportation cost (kyat) & 177 & 58.4 \\
$\quad<5000$ & 114 & 37.6 \\
$5000-10,000$ & 12 & 4.0 \\
$>10,000$ & 75 & \\
Language barrier to accessing health care services & \\
Yes & 228 & 24.8 \\
No & 75.2 \\
Getting free-of-charge medical costs & \\
Yes & 157 & 51.8 \\
No & 146 & 48.2
\end{tabular}

Knowledge related to TB prevention and care

$\begin{array}{lll}\text { Low } & 176 & 58.1 \\ \text { High } & 127 & 41.9\end{array}$

Attitude related to TB prevention and care

$\begin{array}{lll}\text { Negative } & 192 & 63.4\end{array}$

Positive $\quad 111 \quad 36.6$

Tuberculin skin test results after $48 \mathrm{~h}$

\begin{tabular}{cll} 
Negative $(<10 \mathrm{~mm})$ & 240 & 79.2 \\
Positive $(\geq 10 \mathrm{~mm})$ & 63 & 20.8 \\
Village No.1 & $20 / 97$ & 20.6 \\
Village No.2 & $29 / 140$ & 20.7 \\
Village No.3 & $14 / 66$ & 21.2 \\
\hline
\end{tabular}

abuse substances. Therefore, males have more opportunity for TB exposure.

We also found that people who were divorced had a greater chance of $\mathrm{TB}$ infection than people who were single, which is consistent with a study in Ethiopia that showed that unmarried people were at higher risk of TB infection than married people [29]. However, a study in South Africa reported that people who were single had a greater chance for TB infection than other groups [30]. This difference may be due to the difference in the study populations. Our study investigated members of the general population living in a village, and the study in South Africa was performed with HIV/ADS patients.

One interesting result from the present study was the association of TB with the use of charcoal and wood as the main source of fuel for cooking, particularly among participants who cooked indoors. This finding is supported by a study in Ghana that reported that people who were charcoal producers and cooked indoors with charcoal were at a higher risk for TB infection than their counterparts [31]. A study in Nepal also clearly demonstrated an association between indoor cooking with charcoal and wood and later TB infection [32]. A study in India reported that people who cooked indoors were 
Table 3 Health behaviors

\begin{tabular}{|c|c|c|}
\hline Health behaviors & $\mathrm{n}$ & $\%$ \\
\hline \multicolumn{3}{|l|}{ Smoking } \\
\hline Yes & 41 & 13.5 \\
\hline Quit & 33 & 10.9 \\
\hline No & 229 & 75.6 \\
\hline \multicolumn{3}{|c|}{ Number of cigarettes per day (piece) } \\
\hline$\leq 10$ & 49 & 66.2 \\
\hline$>10$ & 25 & 33.8 \\
\hline \multicolumn{3}{|l|}{ Alcohol use } \\
\hline Yes & 42 & 13.9 \\
\hline No & 261 & 86.1 \\
\hline \multicolumn{3}{|c|}{ Frequency of alcohol use } \\
\hline Nearly daily & 3 & 7.0 \\
\hline Weekly & 17 & 39.5 \\
\hline Monthly & 23 & 53.5 \\
\hline \multicolumn{3}{|l|}{ Heroin use } \\
\hline Yes & 10 & 3.3 \\
\hline No & 293 & 96.7 \\
\hline \multicolumn{3}{|l|}{ Amphetamine use } \\
\hline Yes & 18 & 5.9 \\
\hline No & 285 & 94.1 \\
\hline \multicolumn{3}{|l|}{ Opium use } \\
\hline Yes & 8 & 2.6 \\
\hline No & 295 & 97.4 \\
\hline
\end{tabular}

Table 4 Environmental factors of the participants

\begin{tabular}{lll}
\hline Factors & $\mathbf{n}$ & \% \\
\hline Type of housing & 42 & 13.9 \\
Bamboo and thatch house & 81 & 26.7 \\
Wooden house & 180 & 59.4 \\
Brick house & & \\
Main source of fuel for cooking & 66 & 21.8 \\
Electricity & 14 & 4.6 \\
Gas & 223 & 73.6 \\
Wood and charcoal & & \\
Indoor cooking & 68 & 22.4 \\
$\quad$ No & 235 & 77.6 \\
$\quad$ Yes & & \\
Type of fuel for indoor cooking & 80 & 73.6 \\
$\quad$ Electric & 223 & \\
Wood and charcoal &
\end{tabular}

at a greater risk of TB infection than people who did not [33]. The findings from studies in Europe [34] and South Africa [35] also demonstrated that indoor cooking was a risk factor for TB, particularly people who used solid fuel (i.e., coal and biomass). People who used charcoal and wood for cooking inside houses with poor ventilation, such as the people in the villages investigated in the present study, were much more likely to contract TB.

Many studies [36, 37] reported that household contact with TB patients was a major risk factor for TB infection in family members. However, our study found that contact with family members who were diagnosed with TB infection was not a risk factor in the multivariate analysis. This difference may be because most people in these villages have a similar degree of exposure to people with $\mathrm{TB}$ as a result of living an area with a high prevalence of $\mathrm{TB}$.

Finally, we found that people who had a poor knowledge of TB prevention and care were more at risk for TB infection than people who had a high level of knowledge. Several studies [38-41] demonstrated the effect of low knowledge of TB prevention and care on TB infection in different communities in various countries. People with less knowledge are likely to lack the skills and practices needed to prevent $\mathrm{TB}$ infection, unlike people who have good level of knowledge. Adequate knowledge is commonly associated with having a relatively high level of education, and people who have a high level of education are relatively more likely to engage in the practices needed to prevent TB infection. People with higher levels of education are also likely to live in a better environment because they are have a higher socioeconomic status.

The present study has a few limitations. We used the TST to identify TB infection due to the limited tools available for TB screening in the area. Even the sputum method was very difficult to manage due to the lack of medical laboratories in the study area. However, the PPD used in the study had a high sensitivity of $94.0 \%$ but a low specificity of $88.0 \%$, which indicates the possibility of false positives. Therefore, it was recommended that people who had a positive result undergo further investigation and treatment at a local hospital if needed. There are several ethnic groups living in the study area, some of whom are not fluent in Burmese. We asked the local public health staff who were fluent in Burmese and the local language to translate on some occasions during the study.

\section{Conclusion}

People in some communities in Shan State near the Thailand border, are living with a high prevalence of TB, particularly people aged $18-59$ years. Many people use 
Table 5 Univariate and multivariate analyses to detect factors associated with TB infection

\begin{tabular}{|c|c|c|c|c|c|c|c|}
\hline \multirow[t]{2}{*}{ Characteristics } & \multicolumn{2}{|c|}{ Yes } & \multicolumn{2}{|l|}{ No } & \multirow[t]{2}{*}{ OR } & \multirow[t]{2}{*}{$95 \% \mathrm{Cl}$} & \multirow[t]{2}{*}{$p$-valt } \\
\hline & $n$ & $\%$ & $n$ & $\%$ & & & \\
\hline \multicolumn{8}{|l|}{ Age (years) } \\
\hline $18-24$ & 10 & 16.4 & 51 & 83.6 & 0.45 & $0.16-1.23$ & 0.121 \\
\hline $24-34$ & 14 & 17.1 & 68 & 82.9 & 0.47 & $0.18-1.21$ & 0.119 \\
\hline $35-44$ & 14 & 23.0 & 47 & 77.0 & 0.68 & $0.26-1.77$ & 0.436 \\
\hline $45-54$ & 15 & 22.7 & 51 & 77.3 & 0.67 & $0.26-1.73$ & 0.415 \\
\hline$\geq 55$ & 10 & 30.3 & 23 & 69.7 & 1.00 & & \\
\hline
\end{tabular}

Sex

\begin{tabular}{|c|c|c|c|c|c|c|c|c|c|c|}
\hline Male & 32 & 29.9 & 75 & 70.1 & 2.27 & $1.29-3.99$ & $0.004^{*}$ & 2.51 & $1.32-4.76$ & $0.005^{*}$ \\
\hline Female & 31 & 15.8 & 165 & 84.2 & 1.00 & & & 1.00 & & \\
\hline
\end{tabular}

BMI $\left(\mathrm{kg} / \mathrm{m}^{2}\right)$

$\begin{array}{llllllll}\text { Underweight }(<18.5) & 11 & 21.6 & 40 & 78.4 & 0.75 & 0.20-2.84 & 0.679 \\ \text { Normal }(18.5-24.9) & 33 & 19.1 & 140 & 80.9 & 0.64 & 0.19-2.16 & 0.481 \\ \text { Overweight }(25-29.9) & 15 & 23.4 & 49 & 76.6 & 0.84 & 0.23-3.03 & 0.792 \\ \text { Obese }(\geq 30.0) & 4 & 26.7 & 11 & 73.3 & 1.00 & & \end{array}$

\section{Religion}

Buddhist

Christian

Other

\section{Ethnicity}

$\begin{array}{llllllll}\text { Burmese } & 11 & 14.3 & 66 & 85.7 & 1.66 & 0.19-14.34 & 0.642 \\ \text { Shan } & 8 & 17.8 & 37 & 82.2 & 2.16 & 0.24-19.37 & 0.491 \\ \text { Ahka } & 23 & 28.4 & 58 & 71.6 & 3.96 & 0.48-32.76 & 0.201 \\ \text { Lahu } & 20 & 22.5 & 69 & 77.5 & 2.89 & 0.35-24.02 & 0.324 \\ \text { Other } & 1 & 9.1 & 10 & 90.9 & 1.00 & & \end{array}$

\section{Marital status}

Single

Ever married

\section{Education}

Illiterate
Primary school
Secondary school
High school
University

\section{Occupation}

Unemployed
Unskilled labor
Private employer
Government staff
Own business

Family income (kyat)

$$
\begin{aligned}
& \leq 100,000 \\
& 100,001-200,000
\end{aligned}
$$

$\begin{array}{lllll}19 & 15.8 & 101 & 84.2 & 0.30 \\ 39 & 22.9 & 131 & 77.1 & 0.48 \\ 5 & 38.5 & 8 & 61.5 & 1.00\end{array}$

$0.08-1.02$

0.054

$0.14-1.54 \quad 0.215$

$\begin{array}{lllll}5 & 38.5 & 8 & 61.5 & 1.00\end{array}$

$$
1
$$

\section{$10 \quad 12$.}

$45 \quad 22.6$

$8 \quad 32.0$

69

154

87.3

77.4

68.0

2.01

17

$34 \quad 27.0$

$6 \quad 25.0$

92

$$
73.0
$$

75.0

$\begin{array}{lll}5 & 15.1 & 28\end{array}$

84.9

2.18

1.16

81.1

1.52

$\begin{array}{lll}7 & 18.9 & 30\end{array}$

$\begin{array}{lll}11 & 13.3 \quad 72\end{array}$

86.7

1.00

$\begin{array}{lll}12 & 18.2 & 54 \\ 9 & 20.4 & 35 \\ 1 & 5.0 & 19 \\ 14 & 17.3 & 67 \\ 27 & 29.4 & 65\end{array}$

81.8

$79.6 \quad 1.15$

95.0

82.7

0.23

0.94

$0.96-4.23$

$1.11-9.47$

0.064

$0.031^{*}$

1.14-5.10

$0.020^{*}$

0.71-6.69

0.172

$0.37-3.66$

0.789

$0.54-4.31$

0.424

70.6

1.86

$0.44-3.03$

0.766

0.02-1.94

0.180

$0.40-2.20$

0.887

0.86-4.03

0.111

$\begin{array}{lllllll}33 & 26.0 & 94 & 74.0 & 1.05 & 0.31-3.49 & 0.932 \\ 21 & 18.1 & 95 & 81.9 & 0.66 & 0.19-2.26 & 0.512\end{array}$


Table 5 Univariate and multivariate analyses to detect factors associated with TB infection (Continued)

\begin{tabular}{|c|c|c|c|c|c|c|c|}
\hline \multirow[t]{2}{*}{ Characteristics } & \multicolumn{2}{|c|}{ Yes } & \multicolumn{2}{|l|}{ No } & \multirow[t]{2}{*}{ OR } & \multirow[t]{2}{*}{$95 \% \mathrm{Cl}$} & \multirow[t]{2}{*}{$p$-valt } \\
\hline & $\mathrm{n}$ & $\%$ & $\mathrm{n}$ & $\%$ & & & \\
\hline $200,001-400,000$ & 5 & 11.4 & 39 & 88.6 & 0.46 & $0.10-2.04$ & 0.313 \\
\hline$>400,000$ & 4 & 25.0 & 12 & 75.0 & 1.00 & & \\
\hline \multicolumn{8}{|c|}{ Number of family members (persons) } \\
\hline$\leq 5$ & 40 & 19.7 & 163 & 80.3 & 1.71 & $0.20-14.36$ & 0.618 \\
\hline $6-10$ & 22 & 23.9 & 70 & 76.1 & 2.20 & $0.25-18.38$ & 0.472 \\
\hline$>10$ & 1 & 12.5 & 7 & 87.5 & 1.00 & & \\
\hline
\end{tabular}

History of BCG vaccination

$\begin{array}{llllllll}\text { No } & 29 & 21.8 & 104 & 78.2 & 1.12 & 0.64-1.95 & 0.701 \\ \text { Yes } & 34 & 20.0 & 136 & 80.0 & 1.00 & & \end{array}$

Family member(s) with history of TB disease

$\begin{array}{llllllll}\text { Yes } & 34 & 29.3 & 82 & 70.7 & 2.25 & 1.28-3.96 & 0.005^{*} \\ \text { No } & 29 & 15.5 & 158 & 84.5 & 1.00 & & \end{array}$

\section{HIV/AIDS testing}

$\begin{array}{llllllll}\text { Yes } & 17 & 20.2 & 67 & 79.8 & 0.95 & 0.51-1.78 & 0.883 \\ \text { No } & 46 & 21.0 & 173 & 79.0 & 1.00 & & \end{array}$

Diabetes mellitus

$\begin{array}{llllllll}\text { Yes } & 3 & 25.0 & 9 & 75.0 & 1.28 & 0.33-4.88 & 0.715 \\ \text { No } & 60 & 20.6 & 231 & 79.4 & 1.00 & & \end{array}$

\section{Smoking}

$\begin{array}{llllllll}\text { Yes } & 14 & 34.2 & 27 & 65.8 & 2.30 & 1.11-4.77 & 0.024^{*} \\ \text { Quit } & 7 & 21.2 & 26 & 78.8 & 1.19 & 0.48-2.94 & 0.693 \\ \text { No } & 42 & 18.3 & 187 & 81.7 & 1.00 & & \end{array}$

Number of cigarettes smoked per day (piece)
0-10
$10 \quad 20.4$
$>10$
$11 \quad 44.0 \quad 14$
$79.6 \quad 1.00$
$56.0 \quad 3.06$
$1.07-8.77 \quad 0.037^{*}$

Alcohol use

$\begin{array}{llllllll}\text { Yes } & 8 & 19.0 & 34 & 81.0 & 0.88 & 0.38-2.01 & 0.764 \\ \text { No } & 55 & 21.1 & 206 & 78.9 & 1.00 & & \end{array}$

Heroin use

$\begin{array}{llllllll}\text { Yes } & 5 & 50.0 & 5 & 50.0 & 4.05 & 1.13-14.46 & 0.031^{*} \\ \text { No } & 58 & 19.8 & 235 & 80.2 & 1.00 & & \\ \text { Amphetamine use } & & & & & & & \\ \text { Yes } & 8 & 44.4 & 10 & 55.6 & 3.34 & 1.26-8.87 & 0.015^{*} \\ \text { No } & 55 & 19.3 & 230 & 80.7 & 1.00 & & \end{array}$

Opium use

$\begin{array}{llllllll}\text { Yes } & 4 & 50.0 & 4 & 50.0 & 4.00 & 0.97-16.46 & 0.055 \\ \text { No } & 59 & 20.0 & 236 & 80.0 & 1.00 & & \end{array}$

Main source of energy for cooking

\begin{tabular}{|c|c|c|c|c|c|c|c|c|c|c|}
\hline Electric & 4 & 6.1 & 62 & 93.9 & 1.00 & & & & & \\
\hline Gas & 1 & 7.1 & 13 & 92.9 & 1.19 & $0.12-11.55$ & 0.879 & 0.73 & $0.07-10.82$ & 0.900 \\
\hline Wood and charcoal & 58 & 26.0 & 165 & 74.0 & 3.15 & $1.89-15.63$ & $0.001^{*}$ & 4.23 & $1.25-9.64$ & $0.025^{*}$ \\
\hline \multicolumn{11}{|l|}{ ndoor cooking practice } \\
\hline No & 12 & 17.6 & 56 & 82.4 & 1.00 & & & & & \\
\hline
\end{tabular}


Table 5 Univariate and multivariate analyses to detect factors associated with TB infection (Continued)

\begin{tabular}{|c|c|c|c|c|c|c|c|c|c|c|}
\hline \multirow[t]{2}{*}{ Characteristics } & \multicolumn{2}{|c|}{ Yes } & \multicolumn{2}{|l|}{ No } & \multirow[t]{2}{*}{ OR } & \multirow[t]{2}{*}{$95 \% \mathrm{Cl}$} & \multirow[t]{2}{*}{$p$-value } & \multirow[t]{2}{*}{ AOR } & \multirow[t]{2}{*}{ 95\% Cl } & \multirow[t]{2}{*}{$p$-value } \\
\hline & $\bar{n}$ & $\%$ & $\bar{n}$ & $\%$ & & & & & & \\
\hline Yes & 51 & 21.7 & 184 & 78.3 & 1.29 & $0.64-2.59$ & 0.469 & & & \\
\hline \multicolumn{11}{|c|}{ Distance to health center (miles) } \\
\hline$\leq 5$ & 57 & 19.4 & 237 & 80.6 & 1.00 & & & & & \\
\hline$>5$ & 6 & 66.7 & 3 & 33.3 & 8.31 & $2.01-34.25$ & $0.003^{*}$ & & & \\
\hline \multicolumn{11}{|c|}{ Language barrier during accessing health care services } \\
\hline Yes & 23 & 30.7 & 52 & 69.3 & 2.07 & $1.14-3.78$ & $0.016^{*}$ & & & \\
\hline No & 40 & 17.5 & 188 & 82.5 & 1.00 & & & & & \\
\hline \multicolumn{11}{|c|}{ Knowledge on TB prevention and care } \\
\hline Low & 51 & 27.1 & 137 & 72.9 & 3.19 & $1.62-6.30$ & $0.001^{*}$ & 4.49 & $1.88-10.72$ & $0.001^{*}$ \\
\hline High & 12 & 10.4 & 103 & 89.6 & 1.00 & & & 1.00 & & \\
\hline \multicolumn{11}{|c|}{ Attitude on TB prevention and care } \\
\hline Negative & 48 & 22.2 & 168 & 77.8 & 1.37 & $0.72-2.60$ & 0.335 & & & \\
\hline Positive & 15 & 17.2 & 72 & 82.8 & 1.00 & & & & & \\
\hline
\end{tabular}

*Significant level at $a=0.05$

charcoal and wood as their main source of fuel for indoor cooking, and many lack adequate knowledge of TB prevention and care. Many are vulnerable to TB infection, particularly males and divorced individuals. Public health interventions that focus on mass screening using a proper tool in rural areas should be implemented to identify latent $\mathrm{TB}$ infection and proper treatment in communities. Collaborations between national and international organizations are urgently needed to reduce the TB burden and help meet the UN's goal of eradicating TB in the near future.

\section{Abbreviations}

AOR: Adjusted odds ratio; AIDS: Acquired immunodeficiency syndrome: BCG: Bacillus Calmette-Guérin; CDC: Centers for Disease Control and Prevention; Cl: Confidence interval; COR: Crude odds ratio; GDP: Gross domestic product; HIV: Human immunodeficiency virus; IOC: Item-objective congruence; OR: Odds ratio; AOR: Adjusted odds ratio; TB: Tuberculosis; PPD: Purified protein derivative; SD: Standard deviation; TST: Tuberculin skin test; UN: United Nations; WHO: World Health Organization

\section{Acknowledgments}

We thank Mae Fah Luang University and The Center of Excellence for The Hill Tribe Health Research for support in the form of grants. We are also grateful for all health care workers who worked in the study setting for their assistance in obtaining access and recruiting participants. Finally, we thank all of the participants for their participation in the study.

\section{Authors' contributions}

TTL: designed the study, collected the data, analyzed the data, and approved the final version of the manuscript. TA: designed the study, analyzed the data, drafted the manuscript, and approved the final version of the manuscript. JS: designed the study and approved the final version of the manuscript. PU, RT, CC, and FY: contacted the villages, collected the data, and approved the final version of the manuscript. WS, and RS: collected data, drafted the manuscript, and approved the final version of the manuscript.

\section{Funding}

This study was supported by a grant from the Center of Excellence for Hill Tribe Health Research, Mae Fa Luang Thailand. The funder had no role in the design of the study, collection, analysis, and interpretation of the data and writing of the manuscript.

Availability of data and materials

The datasets used and/or analysed during the current study are available from the corresponding author on reasonable request.

\section{Ethics approval and consent to participate}

All research protocols and tools were reviewed and approved by the Mae Fah Laung Human Research Ethics Committee (No. REH-61215) and the Ministry of Public Health, Myanmar (No. UPH-IRB 43). Before the data were collected, an explanation of the essential information, including the risks involved in participating in the study, were clearly communicated in Burmese to the subjects, who were then asked to provide informed consent by written on a voluntary basis.

\section{Consent for publication}

Not applicable.

\section{Competing interests}

The authors declare that they have no competing interests.

Received: 17 January 2020 Accepted: 22 November 2020

Published online: 30 November 2020

\section{References}

1. World Health Organization (WHO). Global tuberculosis report 2019: fact sheet. Available from: https://www.who.int/tb/publications/factsheet_global. pdf?ua=1. Accessed 14 Oct 2019.

2. Faksri K, Kaewprasert O, Ong R, Suriyaphol P, Prammananan T, Teo YY, et al. Comparisons of whole-genome sequencing and phenotypic drug susceptibility testing for mycobacterium tuberculosis causing MDR-TB and XDR-TB in Thailand. Int J Antimicrob Agents. 2019;54(2):109-16.

3. World Health Organization (WHO). Regional and global profile: global tuberculosis report 2019. Available from: https:/www.who.int/tb/ publications/global_report/tb19_Report_regional_global_150ctober2019. pdf?ua=1. Accessed 14 Oct 2019.

4. Bhagya S, Thomas ET, Sasidharan PK. Tuberculosis control in India: refocus on nutrition. Indian J Tuberc. 2019;66(1):26-9.

5. Abhishex M, Suzanne L, Naveen KV. HIV-TB co-infection treatment: modeling and optimal control theory perspectives. J Comput Appl Math. 2016;307:143-61.

6. Tahziba H, Kulshreshtha KK, Yadav VS, Kiran K. HIV and HBV co-infections among patients with active TB disease attending a primary health care 
Centre in a rural area of North India. Egyptain J Chest Dis Tuberc. 2016;65(1): 227-32.

7. Danail JC, Philippe G, Knut L, Andew S, Katherine F, Diana W, et al. The impact of social protection and poverty elimination on global tuberculosis incidence: a statistical modelling analysis of sustainable development goal 1. Lancet Glob Health. 2018;6(5):e514-22.

8. Chindo IB, Lekhraj R, Munn SL, Sherina MS, Normala I, Zubairu L, et al. Effectiveness of health education intervention in improving knowledge, attitude, and practices regarding tuberculosis among HIV patients in general hospital Minna, Nigeria: a randomized control trial. PlosOne. 2018; 13(2):e0192276.

9. Sreenivas AN, Sachdeva KS, Parmar M, Chandra S, Ramachandran R, Kulshrestha N, et al. Standards for TB care in India: a tool for universal access to TB care. Indian J Tuberc. 2015;62(4):200-6.

10. Denue BA, Gashau W, Wuduri ZW, Stephen M, Aliyu S, Ngoshe IY. Impact of insurgency on tuberculosis treatment uptake among TB patients in a tertiary health institution in Maiduguri, northeastern Nigeria. Nigerian Med Pract. 2016;70(2):11-6.

11. The World Bank. World bank country and lending groups 2019. Available from: https://datahelpdesk.worldbank.org/knowledgebase/articles/906519world-bank-country-and-lending-groups. Accessed 17 Oct 2019.

12. World Population Review. Myanmar Population 2019. Available from: http:// worldpopulationreview.com/countries/myanmar-population/13. Accessed 17 Oct 2019

13. Lauren $H$, Daniel H. Negotiating identities and emotional belonging: Shan in northern Thailand. Emot Space Soc. 2016;19:21-8.

14. World Health Organization (WHO). Country profiles for 30 high TB burden countries 2018. Available from: https://www.who.int/tb/publications/global_ report/tb19_Report_country_profiles_15October2019.pdf?ua=1. Accessed 17 Oct 2019.

15. Ministry of Public Health, Thailand. Thailand operational plan to end tuberculosis 2017-2021. Available from: https://www.tbthailand.org/ download/Manual/Thailand\%200perational\%20Plan\%20To\%20End\%20\%2 OTB_2017_2021.pdf. Accessed 17 Octob 2019.

16. Supa V, Pimpawun B. Thailand's health screening policy and practices: the case of Burmese migrants with tuberculosis. Kasetsart J Soc Sci. 2016;37(3): $170-4$.

17. Naomi T, Francois N, Angle MF. Access to free or low-cost tuberculosis treatment for migrants and refugees along the Thailand-Myanmar border in Tak province, Thailand. Int J Equity Health. 2016;15:100.

18. Ministry of Public Health. Thailand operational plan to end tuberculosis 2017-2021. Available from: https://www.tbthailand.org/download/Manual/ Thailand\%200perational\%20Plan\%20To\%20End\%20\%20TB_2017_2021.pdf. Accessed 22 Octob 2019.

19. The United Nation. End TB. Available from: https:/www.un.org/pga/73/ event/fight-to-end-tuberculosis/. Accessed 22 Oct 2019

20. Partners in Health. End TB: Myanmar. Available from: http://www.endtb.org/ myanmar. Accessed 14 Oct 2019.

21. Peter B, Leslie EW, Mark RS, Charles EM. Ethic and sample size. Am J Epidemiol. 2005;161(2):105-10.

22. Hu Y, Zhao Q, Wu L, Wang W, Yuan Z, Xu B. Prevalence of latent tuberculosis infection ant its risk factors in schoolchildren and adolescents in Shanghai, China. Eur J Pub Health. 2013;23(6):1064-9.

23. Thai Red Cross Society. Thai Red Cross tuberculin PPD. Available from: https://www.saovabha.com/en/product_vaccine.asp?nTopic=2. Accessed 22 Oct 2019.

24. Centers for Disease Control and Prevention (CDC). Fact Sheets: Tuberculin skin test. Available from: https://www.cdc.gov/tb/publications/factsheets/ testing/skintesting.htm. Accessed 14 Oct 2019

25. World Health Organization (WHO). Tuberculosis profile: Myanmar 2018. https://extranet.who.int/sree/Reports?op=Replet\&name=NWH_HQ_Reports/ G2/PROD/EXT/TBCountryProfile\&lSO2=MM\&outtype=PDF. Accessed 28 Oct 2019.

26. Horton KC, MacPherson P, Houben RM, White RG, Corbett EL. Sex difference in tuberculosis burden and notification in low and milled income countries: a systematic and meta-analysis. PlosOne. 2016;19(3):e100219 https://doi.org/ 10.371/journal.pmed.1002119.

27. Fernandes $P$, Yichebg $M$, Gaeddert $M, T$ sacogianis $T$. Sex and age differences in mycrobacterium tuberculosis infection in Brazil. Epidemiol Infect. 2018;146(12):1-8. https://doi.org/10.1017/S0950268818001450.
28. Yen YF, Hu HY, Lee YL, Ku PW, Ko MC, Chuang PH, et al. Sexual inequity in incident tuberculosis: a cohort study in Taiwan. BMJ Open. 2018;8:e020142. https://doi.org/10.1136/bmjopen-2017-020142.

29. Tulu B, Dida N, Kassa Y, Taye B. Smear positive pulmonary tuberculosis and its risk factors among tuberculosis suspect in South East Ethiopia: a hospital based cross-sectional study. BMC Res Notes. 2014;7(285). https://doi.org/10. 1186/1756-0500-7-285

30. Rodriguez FA, Agbo SO. An assessment of the risk factors for pulmonary infection among adult patients suffering from human immune deficiency virus attending the wellness clinics at Themba hospital. S Afr Fam Pract. 2015;57(2):106-11.

31. Senya BK, Anim NB, Domson BS, Adu P. Prevalence of asymptomatic Mycobacterium tuberculosis infection in charcoal producers. A cross-sectional study in Kaase, Ghana. J Pathog. 2018:1-4. https://doi.org/10.1155/2018/ 9094803.

32. Pokhrel A, Bates MN, Verma SC, Joshi HS, Screeramareddy CT, Smith KR. Tuberculosis and indoor biomass and kerosene use in Nepal: a case-control study. Environ Health Perspect. 2010;118(4):558-64.

33. Schweitzer MD, Patel V, Mirsaeidi M, Foster A, Kumer N. Does indoor air pollution enhance the risk of tuberculosis infection. Am J Respir Crit Care Med. 2017;195:A3983.

34. Gninafon M, Ade G, Ait-Khaled N, Enarson DA, Chiang CY. Exposure to combustion of solid fuel and tuberculosis: a matched case-control study. Eur Respir J. 2011;38:132-8.

35. Elf JL, Eke O, Rakgokong M, Variava E, Baliram Y, Molhaoleng K, et al. Indoor air pollution from secondhand tobacco smoke, solid fuels, and kerosene in homes with active tuberculosis disease in South Africa. BMC Res Notes. 2017;10(591). https://doi.org/10.1186/s13104-017-2892-2.

36. Saunders MJ, Wingfield T, Datta S, Montoya R, Romos E, Baldwin MR. A household-level score to predict the risk of tuberculosis among contacts of patients with tuberculosis: a derivation and external validation. Lancet Infect Dis. 2020;20:110-22.

37. Hamada Y, Glaziou P, Sismanidis C, Getahun H. Prevention of tuberculosis in household members: estimates of children eligible for treatment. Bull World Health Organ. 2019;97(8):534-47D.

38. Huddart S, Bossuroy T, Pons V, Baral S, Pai M, Delavallade C. Knowledge about tuberculosis and infection prevention behavior: a nine city longitudinal study from India. PlosOne. 2018;13(10):e0206245. https://doi. org/10.1371/journal.pone.0206245.

39. Trajman A, Wakoff-Pereira MF, Ramos-Silva J, Cordeiro-Santose M, Albuqerque MF, Hill PC. Knowledge, attitudes and practices on tuberculosis transmission and prevention among auxiliary healthcare professionals in three Brazilian high-burden cities: a cross-sectional survey. BMC Health Serv Res. 2019;19(532). https://doi.org/10.1186/s12913-4231-x.

40. Luba TR, Tang S, Liu Q, Gebremedhin SA, Kisasi MD, Feng Z. Knowledge, attitude and associated factors towards tuberculosis in Lesotho: a population based study. BMC Infect Dis. 2019;19(96). https://doi.org/10. 1186/s12879-019-3688-x.

41. Hassn AO, Olukolade R, Oqbuji QC, Afolabi S, Okwuonye LC, Kusimon OC, et al. Knowledge about tuberculosis: a precursor to effective TB controlfinding from a follow up national KAP study on tuberculosis among Nigerians. Tuberc Res Treat. 2017; ID 6309092. 1-8. https://doi.org/10.1155/ 2017/63090.

\section{Publisher's Note}

Springer Nature remains neutral with regard to jurisdictional claims in published maps and institutional affiliations.

Ready to submit your research? Choose BMC and benefit from:

- fast, convenient online submission

- thorough peer review by experienced researchers in your field

- rapid publication on acceptance

- support for research data, including large and complex data types

- gold Open Access which fosters wider collaboration and increased citations

- maximum visibility for your research: over $100 \mathrm{M}$ website views per year

At BMC, research is always in progress.

Learn more biomedcentral.com/submission 